Bangladesh J. Plant Taxon. 25(1): 93-99, 2018 (June)

(C) 2018 Bangladesh Association of Plant Taxonomists

\title{
NEW RECORDS OF THREE SPECIES AND A GENUS OF THE EUPHORBIACEAE FOR BANGLADESH
}

\author{
M. Nazim Uddin ${ }^{1}$, M. Oliur Rahman ${ }^{2}$ and M. Atiqur Rahman \\ Department of Botany, University of Chittagong, Chittagong 4331, Bangladesh
}

Keywords: Cleidiocarpon laurinum Airy Shaw; Euphorbia repens K. Koch; Euphorbia pycnostegia Boiss.; First records; Euphorbiaceae; Bangladesh.

\begin{abstract}
Three species belonging to two genera of the family Euphorbiaceae are being reported here as new records for Bangladesh, viz., Cleidiocarpon laurinum Airy Shaw, Euphorbia pycnostegia Boiss. and Euphorbia repens K. Koch. The genus Cleidiocarpon Airy Shaw is also a new generic record for Bangladesh. One cultivated species, Acalypha wilkesiana Muell.-Arg., is reported as addition to the account of the Euphorbiaceae of Bangladesh. Description and photographs of these species are provided.
\end{abstract}

\section{Introduction}

The Euphorbiaceae, one of the largest, most complex and diverse families of angiosperms, is consisted of 334 genera (Webster, 1994) and over 8,000 species (Radcliffe-Smith, 2001). Wurdack et al. (2004) opined that as a pantropical family Euphorbiaceae (s.l.) is composed of 340 genera and approximately 8,000-9,000 species. The family is known from its latest treatment in the Encyclopedia of Flora and Fauna of Bangladesh to be represented in the flora of Bangladesh by 47 genera and 141 species (Ahmed et al., 2008). While examining the collected specimens of the family Euphorbiaceae from different districts of the country and specimens preserved at DACB, DUSH, BFRIH, BCSIRH and HCU we came across some unidentified specimens, and after critical examination they have been identified as Cleidiocarpon laurinum Airy Shaw, collected from Chittagong, Cox's Bazar and Rangamati; Euphorbia pycnostegia Boiss., collected from Khulna, Pabna and Satkhira; and Euphorbia repens K. Koch, collected from Barisal and Khulna districts. These species were neither previously recorded from any part of Bangladesh, nor appeared in any previous relevant literature (Roxburgh, 1814; Hooker, 1886-1888; Prain, 1903; Heinig, 1925; Raizada, 1941; Datta and Mitra, 1953; Sinclair, 1956; Khan and Afza, 1968; Khan and Banu, 1972; Khan, 1972-1987; Alam, 1988; Khan and Rahman, 1989-2002; Khan et al., 1994; Rahman and Hassan, 1995, 2017; Rahman and Uddin, 1997; Uddin and Rahman, 1999; Rashid et al., 2000; Khan and Huq, 2001; Rahman et al., 2001, 2012; Rahman and Khan, 2008; Tutul et al., 2010; Uddin and Hassan, 2010; Arefin et al., 2011; Rahman et al., 2012, 2013; Rahman and Alam, 2013; Rashid and Chowdhury, 2013; Rahman et al., 2015; Arefin et al., 2017). Hence, these species are reported here as new records for Bangladesh.

\section{Materials and Methods}

We collected some interesting specimens belonging to the family Euphorbiaceae from Barisal, Chittagong, Cox's Bazar and Rangamati districts. All collected specimens and some other unidentified specimens of the family Euphorbiaceae preserved at Bangladesh National Herbarium (DACB), Dhaka University Salarkhan Herbarium (DUSH), Herbaria of Chittagong University

\footnotetext{
${ }^{1}$ Department of Botany, Rangamati Government College, Rangamati, Bangladesh.

${ }^{2}$ Department of Botany, University of Dhaka, Dhaka 1000, Bangladesh. Corresponding author. Email: prof.oliurrahman@gmail.com
} 
(HCU), Bangladesh Forest Research Institute (BFRIH), Bangladesh Council for Scientific and Industrial Research (BCSIRH) were critically studied. Examination, identification and description of the specimens were made following standard taxonomic methods and consulting relevant literature (Hooker, 1886-1888; Prain, 1903; Hara et al., 1982; Haridasan and Rao, 1987; Sharma et al., 1993), which resulted in three new angiosperm records for the country. Each of these new records is cited with relevant taxonomic data on current name with synonyms, description, ecology, occurrence in Bangladesh, global distribution and specimens examined. Photograph of each newly recorded species is provided based on herbarium specimen.

\section{Results and Discussion}

The study resulted in recognition of occurrence of one more genus, Cleidiocarpon Airy Shaw with one species C. laurinum Airy Shaw, and two more species belong to the genus Euphorbia L., viz., E. repens K. Koch and E. pycnostegia Boiss. in the flora of Bangladesh. The occurrence of these species from elsewhere in Bangladesh were not reported in any previous taxonomic treatment. The genus Euphorbia L. with 20 species were previously recorded from Bangladesh (Ahmed et al., 2008). However, Cleidiocarpon laurinum Airy Shaw, Euphorbia repens K. Koch and E. pycnostegia Boiss. are reported here as addition to the account of the Euphorbiaceae of Bangladesh.

Cleidiocarpon laurinum Airy Shaw in Kew Bull. 19(2): 313 (1965). Cleidion bishnui Chakrab. \& M. Gangop., J. Econ. Taxon. Bot. 12(2): 473 (1988 publ.1989).

(Fig. 1).

A large shrub or small tree. Leaves alternate, lanceolate, acuminate at apex, cuneate at base, margin entire, coriaceous, discoid gland 4-6, near base of lamina; petiole swollen, geniculate.

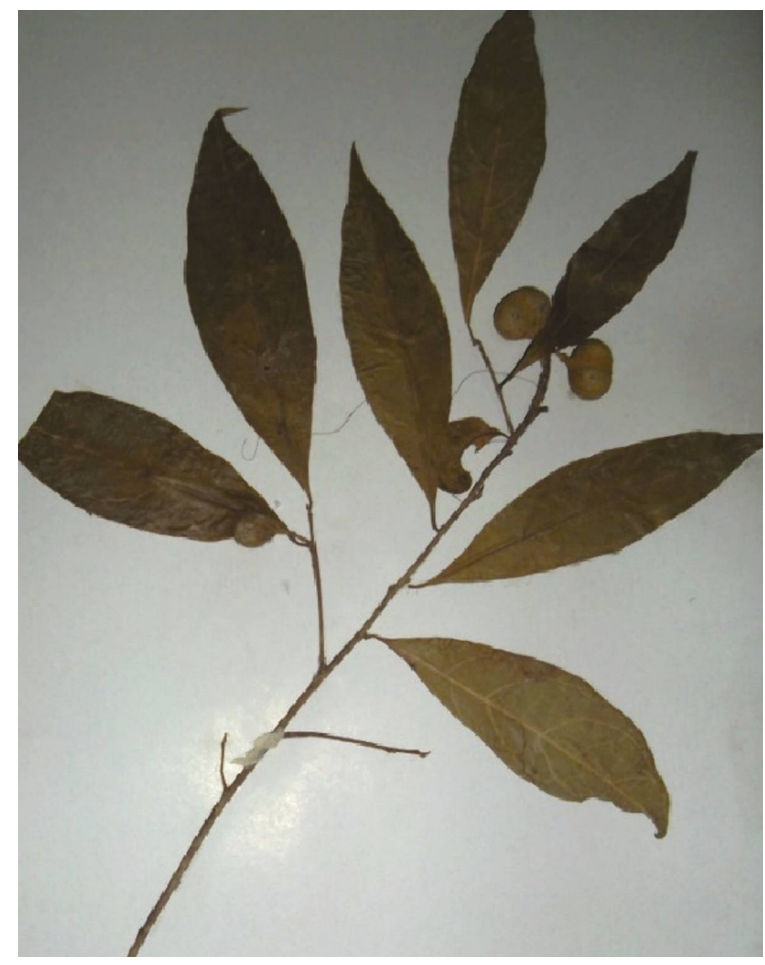

Fig. 1. Cleidiocarpon laurinum Airy Shaw 
Flowers small, monoecious or dioecious. Male flowers: in long axillary racemes; calyx globose, sepals 3-4, valvate, refluxed, glabrous; stamens numerous; anthers 2-celled. Female flowers: solitary, axillary; sepals 3-5, imbricate, thick, ovate; ovary 1-celled; styles 2, very long, each again divided into 2 filiform arms. Fruits capsule, deeply 2-lobed.

Flowering and fruiting: December to April.

Ecology: Rain forests and forest margins.

Occurrence in Bangladesh: Chittagong, Cox's Bazar and Rangamati districts.

Global distribution: Myanmar and Bangladesh.

Specimens examined: Chittagong: Dhopachari, Chamachari, 16.9.1998, Rahman et al. 3393 (HCU); Chandanaish, Dhopachari, 14.6.2013, Uddin et al.10336 (HCU). Cox's Bazar: Panerchara, Tulabagan, 15.10.1998, Rahman et al. 3828 (HCU). Rangamati: Kaptai, Rampahar, 5.11.1999, Rahman 5945 (HCU).

Note: The genus Cleidiocarpon Airy Shaw was not known to be represented in the flora of Bangladesh and this is the new generic record for the country.

Euphorbia pycnostegia Boiss., Cent. Euphorb.: 9 (1860). E. pycnostegia Boiss. var. zornioides (Boiss.) Santapau, Bull. Bot. Soc. Bengal 8: 11 (1955). Chamaesyce zornioides (Boiss.) Soják, Cas. Nár. Mus., Odd. Prír. 140: 170 (1972).

(Fig. 2).

An annual, erect, glabrous herb. Leaves opposite, leaf blade cordately linear-oblong, obtuse or mucronate, serrulate. Flowers distichously imbracting, broadly ovate, cordate. Involucres subsolitary, glabrous, lobes fimbriate, limbs of glands large, entire, rosy, cocci, obtusely angled, glabrous. Seeds smooth or papillose.

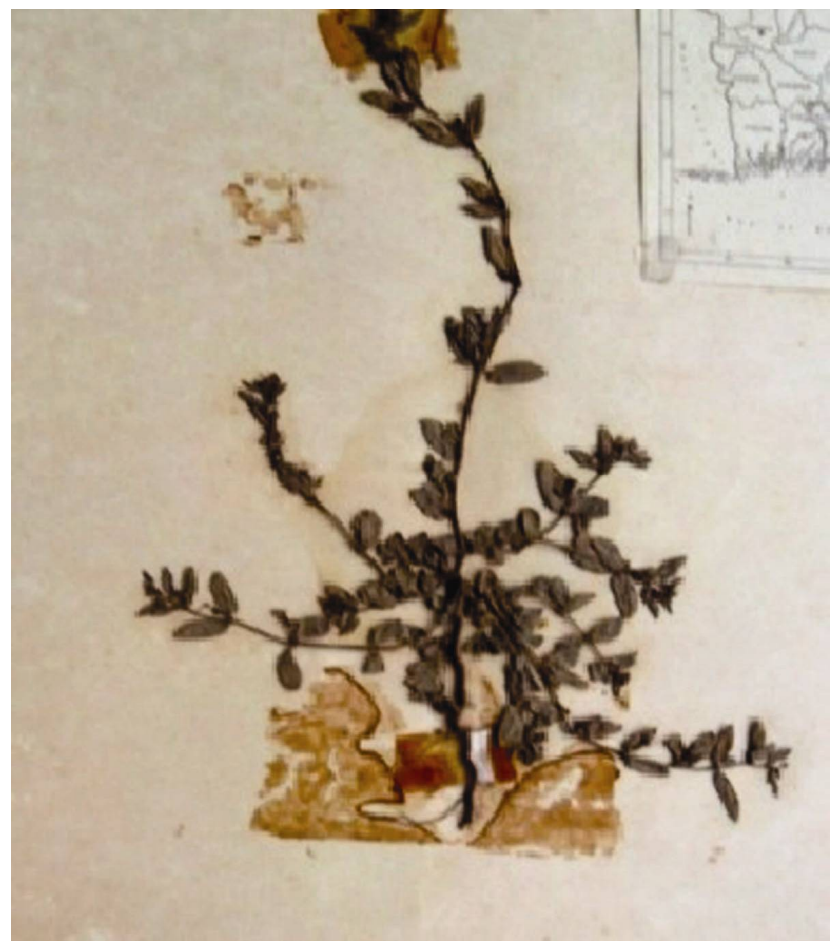

Fig. 2. Habit of Euphorbia pycnostegia Boiss. 
Flowering and fruiting: January to April.

Ecology: Sandy places.

Occurrence in Bangladesh: Khulna, Pabna and Satkhira districts.

Global distribution: India and Bangladesh.

Status of occurrence: Critically Endangered (CR).

Threat to the species: Habitat destruction.

Specimens examined: Khulna: Khulna, 4.1.1966, Tauhid 18 (DACB). Pabna: Pabna, 2.1.1966, Ali 27 (DACB). Satkhira: Satkhira, 27.3.1966, Salahuddin 81 (DACB).

Euphorbia repens K. Koch, Linnaea 21: 728 (1849). Tithymalus repens (K. Koch) Klotzsch \& Garcke, Abh. Königl. Akad. Wiss. Berlin 1859: 96 (1860).

(Fig. 3).

A small, prostrate annual herb with branching stems. Leaves opposite, small, ovate, margin entire. Flower axillary, single on long stalks. Cyathia single, axillary, lobes of the involucre white and red, campanulate to turbinate, shortly pilose outside, marginal lobes 5, ovate, glands 4. Male flowers: few, slightly exserted from involucre. Female flowers: pedicel long; ovary shortly pubescent; style free; stigma 2-lobed. Fruits capsule, ovoid, smooth, shortly pubescent. Seeds ovoid.

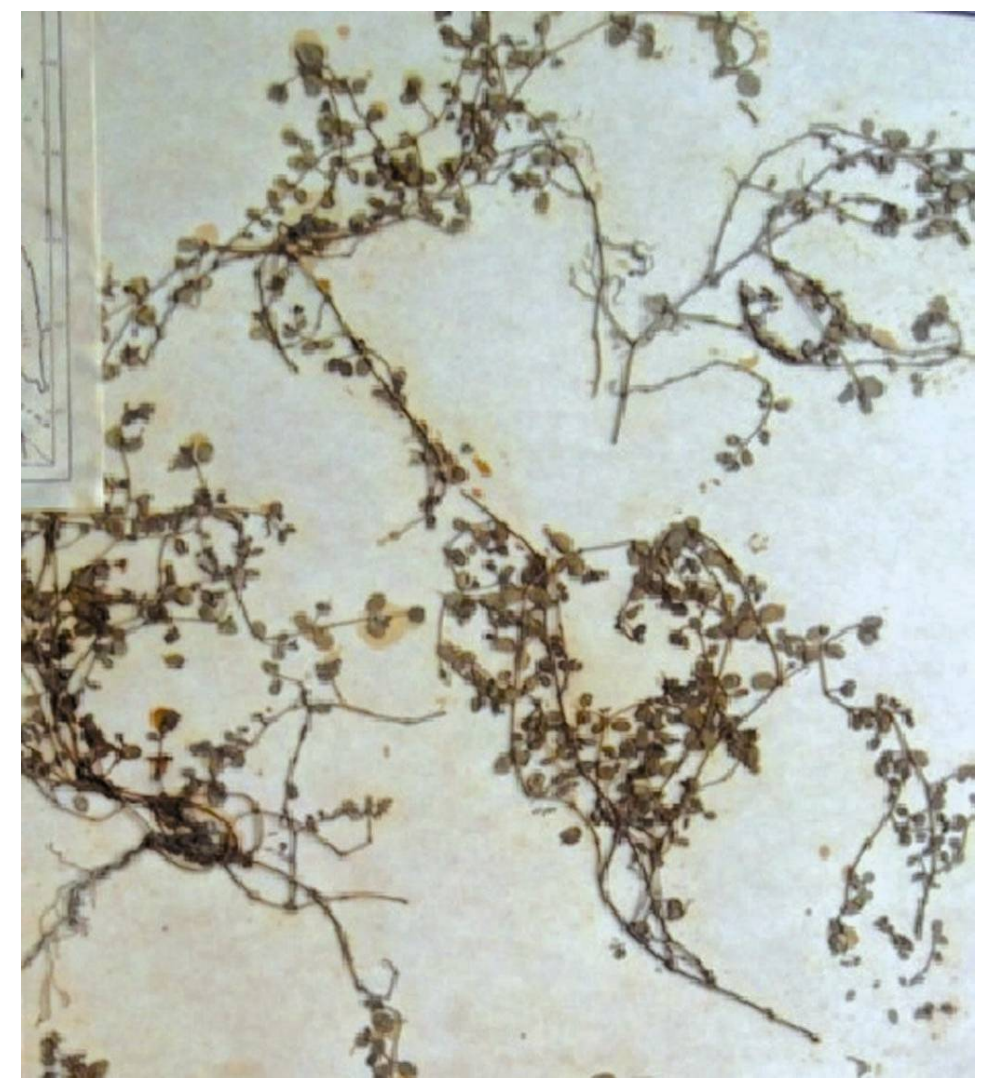

Fig. 3. Habit of Euphorbia repens K. Koch 
Flowering and fruiting: June to September.

Ecology: Mainly a ruderal weed, preferring rough open ground.

Occurrence in Bangladesh: Barisal and Khulna districts.

Global distribution: Africa and Bangladesh.

Status of occurrence: Critically Endangered (CR).

Threat to the species: Habitat destruction.

Specimens examined: Barisal: Bogra, Shahid Zia Smreeti road, Barisal City Corporation area, 18.9.2014, Rahman \& Uddin 11207 (HCU). Khulna: Near Newsprint Mill area, 29.6.1973, Huq 1034 (DACB).

Note: It is reported here as a new record. The first collection of this species was made by A.M. Huq from Khulna in 1973 which is available in DACB. The last collection was made by Rahman and Uddin from Barisal City Corporation area in 2014 which is accessible in HCU.

In addition to above-mentioned three species reported here as new records for Bangladesh, one cultivated species, Acalypha wilkesiana Muell.-Arg., is also recorded as a new addition to the account of the Euphorbiaceae of Bangladesh.

Acalypha wilkesiana Muell.-Arg., Prodr. 15(2): 817 (1866).

A densely branched shrub, monoecious. Leaf blades elliptic-ovate to broadly ovate, obtusely acuminate at apex, cuneate or rounded at base, margin crenate-dentate, many nerved from the base, main veins on both surfaces at first glabrous, later glabrescent, green, coppery or bronze coloured and variously variegated with purple, red, pink, cream-coloured or white or else pinkcream or white margined, lateral nerves in pairs; stipules narrowly lanceolate, acute to acuminate. Inflorescence axillary, usually solitary, spicate, unisexual. Male flowers: sessile or so, buds tetragonal, reddish; anthers yellowish. Female flowers: sessile; sepals ovate; ovary sub-globose, tomentose; style united at the base, deeply laciniate, red. Fruits 3-lobed, pubescent.

Flowering and fruiting: December to April.

Ecology: Cultivated in gardens and along road sides.

Occurrence in Bangladesh: Barisal, Chittagong and Dhaka districts.

Global distribution: Worldwide in (sub-) tropical climates where it is often introduced as an ornamental.

Status of occurrence: Cultivated.

Medicinal uses: In Britain, leaves are used to treat diarrhoea. Likewise, fresh or heated leaves are externally applied to relieve rheumatic pain and inflammation.

Specimens examined: Barisal: Bogra, Shahid Zia Smreeti road, Barisal City Corporation area, 18.9.2014, Rahman \& Uddin 11208 (HCU). Chittagong: Mirsarai forest range, 18.11.1996, Islam 5898 (HCU). Dhaka: Balda Garden, 23.1.1980, Begum 143 (DACB).

\section{Acknowledgements}

The authors are grateful to the authorities of DACB, DUSH, HCU, BFRIH and BCSIRH for giving permission to study their preserved specimens of the Euphorbiaceae.

\section{References}

Ahmed, Z.U., Hassan, M.A., Begum, Z.N.T., Khandker, M., Kabir, S.M.H., Ahmed, M., Ahmed, A.T.A., Rahman, A.K.T. and Haque, E.U. (Eds). 2008. Encyclopedia of Flora and Fauna of Bangladesh. Vol. 7. Asiatic Society of Bangladesh, Dhaka, pp. 376-488. 
Alam, M.K. 1988. Annotated Checklist of the Woody Flora of Sylhet Forest. Bulletin 5. Plant Taxonomy Series, Bangladesh Forest Research Institute, Chittagong, pp. 35-44.

Arefin, M.K., Rahman, M.M., Uddin, M.Z. and Hassan, M.A. 2011. Angiospermic flora of Satchari National Park, Habiganj, Bangladesh. Bangladesh J. Plant Taxon. 18(2): 117-140.

Arefin, M.S., Hossain, M.K. and Hossain, M.A. 2017. Plant diversity of Sonadia island - An ecologically critical area of south-east Bangladesh. Bangladesh J. Plant Taxon. 24(1): 107-116.

Datta, R.M. and Mitra, J.N. 1953. Common plants in and around Dacca. Bull. Bot. Soc. Bengal. 7(1\&2): 25-30.

Hara, H., Chater, A.O. and Williams, L.H.J. 1982. An Enumeration of the Flowering Plants of Nepal. British Museum (Natural History), London 3: 139-199.

Haridasan, K. and Rao, R.R. 1987. Forest flora of Meghalaya. Bishen Singh Mahendra Pal Singh, Dehra Dun, India, 2: 479-480.

Heinig, R.L. 1925. List of Plants of Chittagong Collectorate and Hill Tracts. The Bengal Government Press, Darjeeling, India, pp. 55-59.

Hooker, J.D. 1886-1888. Flora of British India, Vol. 5. L. Reeve and Co. Ltd., Kent, England, pp. 239-477.

Khan, M.S. (Ed.). 1972-1987. Flora of Bangladesh. Fasc. 1-59. Bangladesh National Herbarium, Bangladesh Agricultural Research Council, Dhaka.

Khan, M.S. and Afza, S.K. 1968. A taxonomic report on the angiospermic flora of Teknaf and St. Martin's Island. Dhaka Univ. Studies, Part B. 16: 35-37.

Khan, M.S. and Banu, F. 1972. A taxonomic report on the angiospermic flora of Chittagong Hill Tracts-2 (Dicotyledons). J. Asiat. Soc. Bang. 17(2): 59-88.

Khan, M.S. and Huq, A.M. 2001. The vascular flora of Chunati Wildlife Sanctuary in south Chittagong, Bangladesh. Bangladesh J. Plant Taxon. 8(1): 47-64.

Khan, M.S. and Rahman, M.M. (Eds). 1989-2002. Flora of Bangladesh. Fasc. 40-53. Bangladesh National Herbarium, Dhaka.

Khan, M.S., Rahman, M.M., Huq, A.M., Mia, M.M.K. and Hassan, M.A.1994. Assessment of biodiversity of Teknaf Game Reserve in Bangladesh focusing on economically and ecologically important plant species. Bangladesh J. Plant Taxon. 2(1\&2): 47-79.

Prain, D. 1903. Bengal Plants, Vol. 2. Bishen Singh Mahendra Pal Singh, Dhera Dun, India, pp. 694-716.

Radcliffe-Smith, A. 2001. Genera Euphorbiacearum. Royal Botanic Gardens, Kew, London, 464 pp.

Rahman, M.A. and Uddin, S.B. 1997. Assessment of plant diversity of Sitakunda in Chittagong. Bangladesh J. Plant Taxon. 4(1): 17-36.

Rahman, M.M., Rashid, M.H. and Rashid, S.H. 2001. Assessment of plant biodiversity of sand dune ecosystem along the Cox's Bazar to Teknaf coast. Bangladesh J. Plant Taxon. 8(1): 27-45.

Rahman, M.A., Uddin, M.N., Rashid, M.E. and Islam, M.M. 2012. Floristic diversity in Rampahar reserve forest of Kaptai, Rangamati. Biodiversity Bull. 6: 1-31.

Rahman, M.O. and Alam, M.T. 2013. A taxonomic study on the angiosperm flora of Trishal upazila, Mymensingh. Dhaka Univ. J. Biol. Sci. 22(1): 63-74.

Rahman, M.O. and Hassan, M.A. 1995. Angiospermic flora of Bhawal National Park, Gazipur (Bangladesh). Bangladesh J. Plant Taxon. 2(1\&2): 47-79.

Rahman, M.O. and Hassan, M.A. 2017. New angiospermic taxa for the flora of Bangladesh. Bangladesh J. Plant Taxon. 24(2): 165-171.

Rahman, M.O. and Khan, B. 2008. Euphorbiaceae. In: Ahmed, Z.U., Hassan, M.A., Begum, Z.N.T., Khandker, M., Kabir, S.M.H., Ahmed, M., Ahmed, A.T.A., Rahman, A.K.T. and Haque, E.U. (Eds), Encyclopedia of Flora and Fauna of Bangladesh, Vol. 7. Asiatic Society of Bangladesh, Dhaka, pp. 376-488.

Rahman, M.O., Begum, M. and Ullah, M.W. 2013. Angiosperm flora of Sadar upazila of Munshigonj district, Bangladesh.Bangladesh J. Plant Taxon. 20(2): 213-231. 
Rahman, M.O., Antara, R.T., Begum, M. and Hassan, M.A. 2012. Floristic diversity of Dhamrai upazila of Dhaka, Bangladesh with emphasis on medicinal plants. Bangladesh J. Bot. 41(1): 71-85.

Rahman, M.S., Hossain, G.M., Khan, S.A. and Uddin, S.N. 2015. An annotated checklist of the vascular plants of Sundarban mangrove forest of Bangladesh. Bangladesh J. Plant Taxon. 22(1): 17-41.

Rashid, M.H., Rahman, E. and Rahman M.A. 2000. Additions to the angiospermic flora of Moheskhali Island. Bangladesh J. Plant Taxon. 7(1): 43-63.

Rashid, M.H. and Chowdhury, M.A.I. 2013. Additions to the angiosperm flora in the Sitapahar Reserve Forest of Kaptai, Rangamati, Bangladesh. Bangladesh J. Plant Taxon. 20(2): 255-257.

Raizada, M.B. 1941. On the flora of Chittagong. Indian Forester 67(5): 245-254.

Roxburgh, W. 1814. Hortus Bengalensis (num. nud.). Boerhave Press, Leiden (Holland), 105 pp.

Sharma, B.D., Balakrishnan, N.P., Rao, R.R. and Hajra, P.K. 1993. Flora of India, Botanical Survey of India, Calcutta 1: 1-467.

Sinclair, J. 1956. The Flora of Cox's Bazar, East Pakistan. Bull. Bot. Soc. Beng. 9(2): 105-106.

Tutul, E., Uddin, M.Z., Rahman, M.O. and Hassan, M.A. 2010. Angiospermic flora of Runctia Sal forest, Bangladesh. II. Magnoliopsida (Dicots). Bangladesh J. Plant Taxon. 17(1) 33-53.

Uddin, M.Z. and Hassan, M.A. 2010. Angiosperm diversity of Lawachara National Park (Bangladesh): A preliminary assessment. Bangladesh J. Plant Taxon. 17(1): 9-22.

Uddin, S.B. and Rahman, M.A. 1999. Angiospermic flora of Himchari National Park, Cox's Bazar. Bangladesh J. Plant Taxon. 6(1): 31-68.

Webster, G.L. 1994. Synopsis of the genera and suprageneric taxa of Euphorbiaceae. Ann. Miss. Bot. Gard. 81: 33-144.

Wurdack, K.J., Hoffmann, P., Samuel, R., Bruijn, A., van der Bank, M. and Chase, M.W. 2004. Molecular phylogenetic analysis of Phyllanthaceae (Phyllanthoideae pro parte. Euphorbiaceae s.l.) using plastid $r b c$ L DNA sequences. Am. J. Bot. 91: 1882-1900. 